Check for updates

Cite this: RSC Adv., 2021, 11, 31377

Received 3rd August 2021

Accepted 24th August 2021

DOI: 10.1039/d1ra05889d

rsc.li/rsc-advances

\section{Tetrazol-Cu(ı) immobilized on nickel ferrite catalyzed green synthesis of indenopyridopyrimidine derivatives in aqueous media $\uparrow$}

\begin{abstract}
Zahra Ghanbari and Hossein Naeimi (DD *
After the initial study of different protocols in the synthesis of indeno[2', $\left.1^{\prime}: 5,6\right]$ pyrido[2,3- $d$ ] pyrimidines, herein, a new method is presented using cheaper and more accessible starting materials to produce high-efficiency products. In this protocol, the novel nanocatalyst is very effective in the progression of the reaction and increasing the efficiency. This green approach in aqueous media has several advantages as compared with other methods, such as easier work-up, very mild reaction conditions, reusability of the catalyst, and eco-friendliness. The products of this four-component condensation were evaluated using IR, ${ }^{1} \mathrm{H} N \mathrm{NMR},{ }^{13} \mathrm{C}$ NMR spectra, and C. H. N. analyses, and the catalyst structure was confirmed by FT-IR, XRD, SEM, EDX, TGA and VSM techniques.
\end{abstract}

\section{Introduction}

The preparation of effective biological compounds with new and simpler methods can be considered a valuable goal for organic chemists. A protocol that brings higher product efficiency despite selecting more available materials is highly desirable. In previous studies, the indenopyridopyrimidine compounds have proven their special therapeutic effects; for example, tuberculostatic, ${ }^{1}$ anticonvulsants, ${ }^{2}$ calcium channel antagonists, ${ }^{3}$ anticancer, ${ }^{4}$ antimicrobial, ${ }^{5}$ antiviral, ${ }^{6}$ diuretic and potassium-sparing, ${ }^{7}$ antifolate, ${ }^{8}$ and antiinflammatory ${ }^{9}$ activities. Previous methods used to prepare this product include three-component reactions using uracil derivatives. ${ }^{10-13}$ From a variety of synthetic routes, the choice of multicomponent reactions (MCRs), as simple, economical, environmentally friendly, and applicable procedures, is desirable to obtain favored drug combinations. This suitable pathway easily prepares various highly functionalized heterocyclic compounds without generating many waste products that are often produced in multi-step reactions. ${ }^{14-27}$ The combination of two reaction paths according to the properties of the material used can help in achieving the desired product. With this view, we have considered the preparation of indenopyridine, ${ }^{28}$ pyridopyrimidines,${ }^{29}$ and pyrimidines,${ }^{30}$ in addition to the consideration of the usual preparation method for indenopyridopyrimidines. ${ }^{31,32}$ With this approach, the product

Department of Organic Chemistry, Faculty of Chemistry, University of Kashan, Kashan, 87317, I. R. Iran. E-mail: naeimi@kashanu.ac.ir; Fax: +98-31-55912397; Tel: +98-3155912388

† Electronic supplementary information (ESI) available. See DOI: 10.1039/d1ra05889d is obtained using barbituric acid and ammonium acetate, instead of uracil, in a four-component reaction.

The use of copper complexes in various chemical reactions, such as alkyne-azide cycloaddition, ${ }^{33}$ hydroboration reactions, ${ }^{34}$ allylic alkylation reactions, ${ }^{35}$ direct addition of terminal alkynes to imines ${ }^{36}$ and $\beta$-boration of $\alpha, \beta$-unsaturated esters, ${ }^{37}$ has led us to the use of these compositions as a catalyst in this reaction.

The choice of magnetic nanoparticles as a catalyst platform in chemical reactions provides a convenient separation of the heterogeneous catalyst at the end of the reaction using an external magnetic field. On the other hand, these valuable platforms have the ability to link with different functional groups for the desired purposes. ${ }^{38}$

Herein, for the first time, we report a new method for the synthesis of indenopyridopyrimidine compounds using $\mathrm{NiFe}_{2}-$ $\mathrm{O}_{4} @ \mathrm{SiO}_{2}$-tetrazol-Cu(I) as the catalyst.

\section{Experimental}

\subsection{Materials}

All commercially available reagents were used without further purification and purchased from the Merck Chemical Company in high purity. All of the used solvents were purified by standard procedure.

\subsection{Apparatus}

IR spectra were obtained as $\mathrm{KBr}$ pellets on a PerkinElmer 781 spectrophotometer and on an impact 400 Nicolet FT-IR spectrophotometer. ${ }^{1} \mathrm{H}$ NMR and ${ }^{13} \mathrm{C}$ NMR were recorded in DMSO$d_{6}$ solvents on a Bruker DRX-400 spectrometer with 
tetramethylsilane as the internal reference. The elemental analyses (C. H. N.) were carried out using a Vario EL Model EA 1108 analyzer.

FE-SEM analysis was carried out using a Jeol SEM instrument (model - VEGA/TESCAN) combined with an INCA instrument for energy-dispersive X-ray spectroscopy scanning electron microscopy (EDS-SEM), with scanning electron electrode at 15 $\mathrm{kV}$. The XRD patterns were recorded on an X-ray diffractometer (Bruker, D8 ADVANCE, Germany). The magnetic properties of the nanoparticles were measured using a vibrating sample magnetometer (VSM, PPMS-9T) at $300 \mathrm{~K}$, Kashan University, Iran. The BANDELIN ultrasonic HD 3200 with probe model KE 76 , of $6 \mathrm{~mm}$ diameter was used to produce ultrasonic irradiation. Thermogravimetric analysis (TGA) was performed on a Mettler TA4000 system TG-50 at a heating rate of $10 \mathrm{~K} \mathrm{~min}^{-1}$ under a $\mathrm{N}_{2}$ atmosphere. Melting points were obtained with a Yanagimoto micro melting point apparatus and are uncorrected. The purity determination of the substrates and reaction monitoring were accomplished by TLC on silica-gel polygram SILG/UV 254 plates (from Merck Company).

\subsection{Catalyst preparation}

General procedure for the preparation of $\mathrm{NiFe}_{2} \mathrm{O}_{4}$ nanoparticles. A $3 \mathrm{M}$ solution of sodium hydroxide (as the precipitating agent) was slowly mixed with salt solutions of $0.4 \mathrm{M}$ ferric chloride $\left(\mathrm{FeCl}_{3} \cdot 6 \mathrm{H}_{2} \mathrm{O}\right)$ and $0.2 \mathrm{M}$ nickel chloride $\left(\mathrm{NiCl}_{2} \cdot 6 \mathrm{H}_{2} \mathrm{O}\right)$. The $\mathrm{pH}$ of the solution was constantly monitored as the $\mathrm{NaOH}$ solution was added dropwise. The reactants were constantly stirred using a magnetic stirrer until a $\mathrm{pH}$ level of $>12$ was achieved. A specified amount of oleic acid (2-3 drops for the total reacting solution of $75 \mathrm{ml}$ ) was added to the solution as the surfactant. The liquid precipitate was then brought to a reaction temperature of $80{ }^{\circ} \mathrm{C}$ and stirred for $40 \mathrm{~min}$. The product was cooled to room temperature and then washed twice with distilled water and ethanol to remove unwanted impurities and the excess surfactant from the prepared sample. The sample was centrifuged for $15 \mathrm{~min}$ at $2000 \mathrm{rpm}$ and then dried overnight at above $80{ }^{\circ} \mathrm{C}$. The acquired substance was then ground into a fine powder and then annealed for $10 \mathrm{~h}$ at $600{ }^{\circ} \mathrm{C} . .^{39}$

General procedure for preparation of the nano- $\mathrm{NiFe}_{2} \mathrm{O}_{4} @$ $\mathrm{SiO}_{2}$ core-shell. The core-shell $\mathrm{NiFe}_{2} \mathrm{O}_{4} @ \mathrm{SiO}_{2}$ nanospheres were prepared by a modified Stober method; ${ }^{40}$ briefly, $\mathrm{NiFe}_{2} \mathrm{O}_{4}$ $(0.5 \mathrm{~g}, 2.1 \mathrm{mmol})$ was dispersed in a mixture of ethanol $(50 \mathrm{ml})$, deionized water $(5 \mathrm{ml})$, and tetraethoxysilane (TEOS) $(0.2 \mathrm{ml})$, followed by the addition of $5.0 \mathrm{ml} \mathrm{NaOH}(10 \% \mathrm{wt})$. This solution was stirred mechanically for $30 \mathrm{~min}$ at room temperature. The product, $\mathrm{NiFe}_{2} \mathrm{O}_{4} @ \mathrm{SiO}_{2}$, was separated by an external magnet and was washed three times with the mixture of deionized water and ethanol and dried at $80{ }^{\circ} \mathrm{C}$ for $10 \mathrm{~h}$. FT-IR $(\mathrm{KBr}$ pellets, $\left.\mathrm{cm}^{-1}\right): 3400(\mathrm{O}-\mathrm{H}), 1023-1151(\mathrm{Si}-\mathrm{O}-\mathrm{Si})$, and $590(\mathrm{Fe}-$ O).

General procedure for the preparation of $\mathrm{NiFe}_{2} \mathrm{O}_{4} @ \mathrm{SiO}_{2}$ tetrazol. $\mathrm{NiFe}_{2} \mathrm{O}_{4} @ \mathrm{SiO}_{2}(1.0 \mathrm{~g})$ was dissolved in $6 \mathrm{ml}$ of pure epichlorohydrin and subjected to ultrasound for 20 minutes. The resulting mixture was stirred and refluxed at $60{ }^{\circ} \mathrm{C}$ for 24 hours. After the reaction, the mixture was washed with ethanol and then completely dried. The resulting product was dissolved in $7 \mathrm{ml}$ of dried DMF and then placed in an ultrasound bath for 20 minutes. Next, $0.6 \mathrm{~g}$ of sodium azide was added to the suspension and the resulting mixture was refluxed for 48 hours. After about 5 hours of the reaction, $0.29 \mathrm{~g}$ of phthalonitrile was added to the reaction mixture, and $0.05 \mathrm{~g}$ of $\mathrm{CuI}$ was added as a catalyst for the formation of the tetrazole ring. After the completion of the reaction, the mixture was smooth and washed with dichloromethane and ethanol, respectively, then dried in an oven at $60{ }^{\circ} \mathrm{C}$ for 12 hours.

General procedure for the preparation of $\mathrm{NiFe}_{2} \mathrm{O}_{4} @ \mathrm{SiO}_{2}$ tetrazol-Cu(I). Here, $0.1 \mathrm{~g}$ of $\mathrm{CuCl}$ was dissolved in $5 \mathrm{ml}$ of ethanol and added to the product obtained from the previous step. The resulting mixture was placed under a nitrogen atmosphere for 4 hours. Vigorous stirring helped to accelerate the reaction. Upon completion of the reaction, the product was washed with acetone and ethanol, respectively, and then dried.

A typical procedure for the synthesis of 5-(4-chlorophenyl)$1 H$-indeno $\left[2^{\prime}, 1^{\prime}: 5,6\right]$ pyrido[2,3- $\left.d\right]$ pyrimidine-2,4,6(3H)-trione. A mixture of 4-chlorobenzaldehyde ( $1 \mathrm{mmol}), 1,3$-indanedione (1 $\mathrm{mmol})$, barbituric acid $(1 \mathrm{mmol})$, and ammonium acetate (1.3 $\mathrm{mmol}$ ) was stirred in water at $95{ }^{\circ} \mathrm{C}$ for the appropriate time. The progress of the reaction was monitored by TLC. After the completion of the reaction, the corresponding solid product was obtained through simple filtering, and recrystallized from hot ethanol to afford the highly pure desired product.

The spectral information of various products, including IR, NMR, and C.H.N. analyses are given below.

5-(4-Chlorophenyl)-1H-indeno[2' $\left.2^{\prime}: 5,6\right]$ pyrido[2,3-d] pyrimidine-2,4,6(3H)-trione (1a). White powder; mp: $258{ }^{\circ} \mathrm{C}$, decompose; IR (KBr) $\left(\nu_{\max } / \mathrm{cm}^{-1}\right): 1413,1558(\mathrm{C}=\mathrm{C}, \mathrm{Ar}), 1634,1693$ $(\mathrm{C}=\mathrm{O}), 3145\left(\mathrm{C}-\mathrm{H}, \mathrm{sp}^{2}\right.$ stretch), 3265, $3444(\mathrm{NH}) .{ }^{1} \mathrm{H}$ NMR $\left(\right.$ DMSO $\left.\mathrm{d}_{6}, 400 \mathrm{MHz}\right) \delta(\mathrm{ppm}): 7.45-7.66(\mathrm{~d}, 2 \mathrm{H}, J=8.0 \mathrm{~Hz})$, 7.51-7.52 (m, 2H), 7.67-7.75 (d, 2H), 7.80-7.82 (d, 2H, $J=8.0$ $\mathrm{Hz}), 9.95(\mathrm{~s}, 1 \mathrm{H}) .{ }^{13} \mathrm{C} \mathrm{NMR}\left(100 \mathrm{MHz}, \mathrm{DMSO}-\mathrm{d}_{6}\right) \delta(\mathrm{ppm}): 123.52$, 125.91, 127.94, 128.68, 130.23, 132.23, 135.48, 139.16, 149.25, 162.75, 165.13, 170.00, 79.00; anal. calcd for $\mathrm{C}_{20} \mathrm{H}_{10} \mathrm{~N}_{3} \mathrm{O}_{3} \mathrm{Cl}$ : C, $64 ; \mathrm{H}, 2.67 ; \mathrm{N}, 11.2 \%$; found: C, 63.91; H, 2.70; N, $11.23 \%$.

5-(4-Methoxyphenyl)-1H-indeno $\left[2^{\prime}, 1^{\prime}: 5,6\right]$ pyrido[2,3-d] pyrimidine-2,4,6(3H)-trione (2a). Yellow powder; mp: $245{ }^{\circ} \mathrm{C}$, decompose, mp (lit) ${ }^{41} 248{ }^{\circ} \mathrm{C}$; IR ( KBr) $\left(\nu_{\max } / \mathrm{cm}^{-1}\right): 1443,1529(\mathrm{C}=\mathrm{C}$, $\mathrm{Ar})$, 1665, $1750(\mathrm{C}=\mathrm{O}), 2916\left(\mathrm{C}-\mathrm{H}, \mathrm{sp}^{3}\right), 3243\left(\mathrm{C}-\mathrm{H}, \mathrm{sp}^{2}\right.$ stretch), 3439, $3585(\mathrm{NH}) .{ }^{1} \mathrm{H}$ NMR (DMSO-d 6 , $\left.400 \mathrm{MHz}\right) \delta(\mathrm{ppm}): 7.02-$ $7.04(\mathrm{~d}, 2 \mathrm{H}, J=8.0 \mathrm{~Hz}), 7.48-7.49(\mathrm{~m}, 2 \mathrm{H}), 7.58-7.60$ (d, 2H, $J=$ $8.4 \mathrm{~Hz}), 7.80-7.81(\mathrm{~m}, 2 \mathrm{H})$. Anal. calcd for $\mathrm{C}_{21} \mathrm{H}_{13} \mathrm{~N}_{3} \mathrm{O}_{4}$ : C, 67.92; $\mathrm{H}, 3.50$; N, $11.32 \%$; found: $\mathrm{C}, 67.91 ; \mathrm{H}, 3.47$; N, 11.35\%.

5-(3-Methoxyphenyl)-1H-indeno $\left[2^{\prime}, 1^{\prime}: 5,6\right]$ pyrido[2,3-d] pyrimidine-2,4,6(3H)-trione (3a). Cream powder; mp: $231{ }^{\circ} \mathrm{C}$, decompose; IR (KBr) $\left(\nu_{\max } / \mathrm{cm}^{-1}\right): 1421,1539(\mathrm{C}=\mathrm{C}, \mathrm{Ar}), 1635,1711$ $(\mathrm{C}=\mathrm{O}), 2922\left(\mathrm{C}-\mathrm{H}, \mathrm{sp}^{3}\right), 3179\left(\mathrm{C}-\mathrm{H}, \mathrm{sp}^{2}\right.$ stretch), 3342, 3467 (NH). ${ }^{1} \mathrm{H}$ NMR (DMSO-d 6 , $\left.400 \mathrm{MHz}\right) \delta(\mathrm{ppm}): 7.04-7.06(\mathrm{~d}, 2 \mathrm{H})$, 7.23 (s, 1H), 7.33-7.35 (m, 2H), 7.51-7.52 (m, 2H), 7.68-7.69 (d, 2H). ${ }^{13} \mathrm{C}$ NMR (100 MHz, DMSO-d 6 ) $\delta$ (ppm): 61.13, 111.67, 112.22 , 118.79, 123.57, 125.91, 127.79, 129.18, 130.20, 135.46, 149.57, 161.71, 169.76, 176.16, 179.48.

5-(3-Chlorophenyl)-1H-indeno[2' $\left.2^{\prime} 1^{\prime}: 5,6\right]$ pyrido[2,3-d] pyrimidine-2,4,6(3H)-trione (4a). Yellow powder; mp: $258{ }^{\circ} \mathrm{C}$, 
decompose; IR (KBr) $\left(\nu_{\max } / \mathrm{cm}^{-1}\right): 1415,1501$ (C=C, Ar), 1645, 1715, $1736(\mathrm{C}=\mathrm{O}), 3241\left(\mathrm{C}-\mathrm{H}, \mathrm{sp}^{2}\right.$ stretch), 3342, $3515(\mathrm{NH}) .{ }^{1} \mathrm{H}$ NMR (DMSO-d 6 , $400 \mathrm{MHz}) \delta(\mathrm{ppm}): 7.07-7.09(\mathrm{~d}, 2 \mathrm{H}), 7.28(\mathrm{~s}$, 1H), 7.44-7.45 (m, 2H), 7.51-7.58 (m, 2H), 7.66-7.68 (d, 2H). Anal. calcd for $\mathrm{C}_{20} \mathrm{H}_{10} \mathrm{~N}_{3} \mathrm{O}_{3} \mathrm{Cl}: \mathrm{C}, 63.93 ; \mathrm{H}, 2.68 ; \mathrm{N}, 11.18 \%$; found: $\mathrm{C}, 65.12 ; \mathrm{H}, 2.53 ; \mathrm{N}, 10.73 \%$.

5-(2-Fluorophenyl)-1H-indeno $\left[2^{\prime}, 1^{\prime}: 5,6\right]$ pyrido[2,3-d] pyrimidine-2,4,6(3H)-trione (5a). Brown powder; mp: $293{ }^{\circ} \mathrm{C}$, decompose; IR (KBr) $\left(\nu_{\max } / \mathrm{cm}^{-1}\right)$ : 1463, $1511(\mathrm{C}=\mathrm{C}, \mathrm{Ar}), 1608,1722$ $(\mathrm{C}=\mathrm{O}), 3192\left(\mathrm{C}-\mathrm{H}, \mathrm{sp}^{2}\right.$ stretch), $3418(\mathrm{NH}) .{ }^{1} \mathrm{H}$ NMR (DMSO-d ${ }_{6}$, $400 \mathrm{MHz}) \delta$ (ppm): 7.42-7.43 (d, 2H), 7.51-7.52 (m, 2H), 7.787.88 (m, 2H), 8.01-8.02 (d, 2H). ${ }^{13} \mathrm{C}$ NMR (100 MHz, DMSO-d 6 ) $\delta$ (ppm): 123.52, 125.93, 127.56, 128.62, 130.26, 131.83, 135.53, 139.14, 149.23, 165.37, 174.18, 176.16. Anal. calcd for $\mathrm{C}_{20} \mathrm{H}_{10} \mathrm{~N}_{3} \mathrm{O}_{3} \mathrm{~F}: \mathrm{C}, 66.85 ; \mathrm{H}, 2.79 ; \mathrm{N}, 11.70 \%$; found: $\mathrm{C}, 66.90 ; \mathrm{H}$, $2.77 ; \mathrm{N}, 11.66 \%$.

5-(o-Tolyl)-1H-indeno $\left[2^{\prime}, 1^{\prime}: 5,6\right]$ pyrido [2,3-d]pyrimidine-

2,4,6(3H)-trione (6a). Cream powder; $\mathrm{mp:} 282^{\circ} \mathrm{C}$, decompose; IR $(\mathrm{KBr})\left(\nu_{\max } / \mathrm{cm}^{-1}\right): 1478,1593(\mathrm{C}=\mathrm{C}, \mathrm{Ar}), 1609,1667,1710(\mathrm{C}=$ O), $2922\left(\mathrm{C}-\mathrm{H}, \mathrm{sp}^{3}\right), 3189\left(\mathrm{C}-\mathrm{H}, \mathrm{sp}^{2}\right.$ stretch), 3313, $3413(\mathrm{NH}) .{ }^{1} \mathrm{H}$ NMR (DMSO-d 6 , $400 \mathrm{MHz}) \delta(\mathrm{ppm}): 2.877$ (s, 3H), 7.07-7.08 (d, 2H), 7.41-743 (m, 2H), 7.51-7.52 (m, 2H), 7.73-7.74 (d, 2H). Anal. calcd for $\mathrm{C}_{21} \mathrm{H}_{13} \mathrm{~N}_{3} \mathrm{O}_{3}$ : C, 70.99; $\mathrm{H}, 3.66 ; \mathrm{N}, 11.83 \%$; found: C, 70.92; H, 3.69; N, 11.87\%.

5-(2,4-Dichlorophenyl)-1H-indeno $\left[2^{\prime}, 1^{\prime}: 5,6\right]$ pyrido[2,3-d] pyrimidine-2,4,6(3H)-trione (7a). Brown powder; mp: $285{ }^{\circ} \mathrm{C}$, decompose, mp (lit) ${ }^{42} 289^{\circ} \mathrm{C}$; IR ( $\left.\mathrm{KBr}\right)\left(\nu_{\max } / \mathrm{cm}^{-1}\right): 1423,1512(\mathrm{C}=\mathrm{C}$, Ar), 1654, 1712, 1728 (C=O), 3241 (C-H, sp ${ }^{2}$ stretch), 3341, 3415 $(\mathrm{NH}) .{ }^{1} \mathrm{H}$ NMR (DMSO-d $\left.{ }_{6}, 400 \mathrm{MHz}\right) \delta(\mathrm{ppm}): 6.95(\mathrm{~s}, 1 \mathrm{H}), 7.33-$ 7.35 (d, 2H), 7.44-7.46 (m, 2H), 7.62-7.64 (d, 2H). Anal. calcd for $\mathrm{C}_{20} \mathrm{H}_{9} \mathrm{~N}_{3} \mathrm{O}_{3} \mathrm{Cl}_{2}$ : C, 58.68; H, 2.20; N, 10.27\%; found: C, $58.65 ; \mathrm{H}$, $2.17 ; \mathrm{N}, 10.30 \%$.

5-(3-Nitrophenyl)-1H-indeno $\left[2^{\prime}, 1^{\prime}: 5,6\right]$ pyrido[2,3-d] pyrimidine2,4,6(3H)-trione (8a). White powder; $\mathrm{mp}: 279{ }^{\circ} \mathrm{C}$, decompose; IR $(\mathrm{KBr})\left(\nu_{\max } / \mathrm{cm}^{-1}\right): 1418,1561(\mathrm{C}=\mathrm{C}, \mathrm{Ar}), 1369,1512(\mathrm{~N}=\mathrm{O})$, 1619, $1711(\mathrm{C}=\mathrm{O}), 2909\left(\mathrm{C}-\mathrm{H}, \mathrm{sp}^{3}\right), 3158\left(\mathrm{C}-\mathrm{H}, \mathrm{sp}^{2}\right.$ stretch), $3509(\mathrm{NH}) .{ }^{1} \mathrm{H}$ NMR (DMSO-d 6 , $\left.400 \mathrm{MHz}\right) \delta(\mathrm{ppm}): 7.13-7.16(\mathrm{~m}$, 2H), 7.33-7.35 (d, 2H), 7.46-7.47 (d, 2H), 7.50-7.55 (m, 2H), 7.66 (s, 1H). ${ }^{13} \mathrm{C}$ NMR (100 MHz, DMSO-d 6 ) $\delta$ (ppm): 121.27, 123.46, 125.86, 127.76, 129.46, 130.24, 134.23, 135.36, 147.63, 149.46, 168.93, 170.57, 177.77. Anal. calcd for $\mathrm{C}_{20} \mathrm{H}_{10} \mathrm{~N}_{4} \mathrm{O}_{5}: \mathrm{C}, 62.18 ; \mathrm{H}$, 2.59; N, 18.13\%; found: C, 62.11; H, 2.57; N, $18.17 \%$.

5-(2-Chlorophenyl)-1H-indeno $\left[2^{\prime}, 1^{\prime}: 5,6\right]$ pyrido $[2,3-d]$ pyrimidine-2,4,6(3H)-trione (9a). Yellow powder; mp: $228{ }^{\circ} \mathrm{C}$, decompose; IR (KBr) $\left(\nu_{\max } / \mathrm{cm}^{-1}\right): 1429,1541(\mathrm{C}=\mathrm{C}, \mathrm{Ar}), 1619,1668$ $(\mathrm{C}=\mathrm{O}), 3219\left(\mathrm{C}-\mathrm{H}, \mathrm{sp}^{2}\right.$ stretch), 3336, $3412(\mathrm{NH}) .{ }^{1} \mathrm{H}$ NMR (DMSO-d 6 , $400 \mathrm{MHz}) \delta(\mathrm{ppm}): 7.07-7.09$ (d, 2H), 7.31-7.33 (m, 2H), 7.50-7.52 (m, 2H), 7.62-7.64 (d, 2H). ${ }^{13} \mathrm{C}$ NMR (100 MHz, DMSO-d $\left.{ }_{6}\right) \delta(\mathrm{ppm}): 123.52,126.23,127.63,128.65,130.23$, 131.83, 135.19, 139.11, 149.20, 168.77, 174.16, 176.44 .

5-(4-Bromophenyl)-1H-indeno[2', $\left.1^{\prime}: 5,6\right]$ pyrido[2,3-d] pyrimidine-2,4,6(3H)-trione (10a). Cream powder; mp: $242{ }^{\circ} \mathrm{C}$, decompose; IR (KBr) $\left(\nu_{\max } / \mathrm{cm}^{-1}\right): 1447,1559(\mathrm{C}=\mathrm{C}, \mathrm{Ar}), 1681,1719$ $(\mathrm{C}=\mathrm{O}), 3072\left(\mathrm{C}-\mathrm{H}, \mathrm{sp}^{2}\right.$ stretch), 3235, $3527(\mathrm{NH}) .{ }^{1} \mathrm{H}$ NMR $\left(\mathrm{DMSO}_{6}, 400 \mathrm{MHz}\right) \delta(\mathrm{ppm}): 7.36-7.38(\mathrm{~d}, 2 \mathrm{H}, J=8.0 \mathrm{~Hz}$ ), 7.53-7.55 (m, 2H), 7.67-7.69 (d, 2H, $J=8.0 \mathrm{~Hz}), 7.724(\mathrm{~d}, 2 \mathrm{H})$. ${ }^{13} \mathrm{C}$ NMR (100 MHz, DMSO-d $\left.\mathrm{d}_{6}\right) \delta$ (ppm): 120.62, 123.50, 125.88,
126.75, 127.81, 130.18, 135.46, 139.13, 141.65, 147.57, 149.23, 168.63, 174.27, 176.64. Anal. calcd for $\mathrm{C}_{20} \mathrm{H}_{10} \mathrm{~N}_{3} \mathrm{O}_{3} \mathrm{Br}$ : C, 57.14; $\mathrm{H}, 2.38$; N, $10 \%$; found: C, 57.11; H, 2.41; N, $10.03 \%$.

5-(5-Methylfuran-2-yl)-1H-indeno $\left[2^{\prime}, 1^{\prime}: 5,6\right]$ pyrido[2,3-d] pyrimidine-2,4,6(3H)-trione (11a). Red brown powder; mp: $339{ }^{\circ} \mathrm{C}$, decompose; IR (KBr) $\left(\nu_{\max } / \mathrm{cm}^{-1}\right): 1423,1531$ (C=C, Ar), 1631, $1733(\mathrm{C}=\mathrm{O}), 2931\left(\mathrm{C}-\mathrm{H}, \mathrm{sp}^{3}\right), 3130\left(\mathrm{C}-\mathrm{H}, \mathrm{sp}^{2}\right.$ stretch), 3242, $3425(\mathrm{NH}) .{ }^{1} \mathrm{H}$ NMR (DMSO-d $\left.6,400 \mathrm{MHz}\right) \delta(\mathrm{ppm}): 2.73(\mathrm{~s}, 3 \mathrm{H})$, 7.45-7.47 (d, 2H), 7.67-7.70 (m, 2H), 7.84-7.87 (d, 2H). Anal. calcd for $\mathrm{C}_{19} \mathrm{H}_{11} \mathrm{~N}_{3} \mathrm{O}_{4}$ : C, 66.08; H, 3.19; N, 12.17\%; found: C, $66.03 ; \mathrm{H}, 3.11 ; \mathrm{N}, 12.21 \%$.

5-(4-Nitrophenyl)-1H-indeno $\left[2^{\prime}, 1^{\prime}: 5,6\right]$ pyrido[2,3-d] pyrimidine2,4,6(3H)-trione (12a). Dark brown powder; mp: $343{ }^{\circ} \mathrm{C}$, decompose, mp (lit) ${ }^{41} 345{ }^{\circ} \mathrm{C}$; IR( $\left.\mathrm{KBr}\right)\left(\nu_{\max } / \mathrm{cm}^{-1}\right): 1433,1531$ $(\mathrm{C}=\mathrm{C}, \mathrm{Ar}), 1317,1553(\mathrm{~N}=\mathrm{O}), 1621,1739(\mathrm{C}=\mathrm{O}), 3205(\mathrm{C}-\mathrm{H}$, $\mathrm{sp}^{2}$ stretch), 3242, $3428(\mathrm{NH}) .{ }^{1} \mathrm{H}$ NMR (DMSO-d $6,400 \mathrm{MHz}$ ) $\delta$ (ppm): 7.754-7.775 (d, 2H, $J=8.0 \mathrm{~Hz}), 7.85-7.86(\mathrm{~m}, 2 \mathrm{H}), 8.18-$ $8.20(\mathrm{~m}, 2 \mathrm{H}), 8.37-8.40(\mathrm{~d}, 2 \mathrm{H}, J=8.4 \mathrm{~Hz})$.

\section{Results and discussion}

3.1. Preparation and characterization of the $\mathrm{NiFe}_{2} \mathrm{O}_{4} @ \mathrm{SiO}_{2}$ tetrazol-Cu(I) catalyst

The preparation of the nickel ferrite nanoparticles using the previously reported method were performed by co-precipitation of $\mathrm{NiCl}_{2}$ and $\mathrm{FeCl}_{3}$ in basic solution at $80{ }^{\circ} \mathrm{C} .{ }^{43}$ Scheme 1 shows the preparation method of the final catalyst. Fourier transform infrared (FT-IR) spectra, X-ray diffraction (XRD), vibrating sample magnetometer (VSM), thermo-gravimetric analysis (TGA), energy-dispersive X-ray spectroscopy (EDX) and scanning electron microscopy (SEM) techniques were utilized to confirm the catalyst structure.

The FT-IR spectra of $\mathrm{NiFe}_{2} \mathrm{O}_{4} \mathrm{NPs}, \mathrm{NiFe}_{2} \mathrm{O}_{4} @ \mathrm{SiO}_{2}, \mathrm{NiFe}_{2}-$ $\mathrm{O}_{4} @ \mathrm{SiO}_{2}$-epoxide and $\mathrm{NiFe}_{2} \mathrm{O}_{4} @ \mathrm{SiO}_{2}$-tetrazol are shown in Fig. 1. The stretching modes of absorbed water appeared in the bands within the range of $3400-1600 \mathrm{~cm}^{-1}$. The vibrations of $\mathrm{Fe}-\mathrm{O}$ and Ni-O bonds were observed at $590 \mathrm{~cm}^{-1}$ and $433 \mathrm{~cm}^{-1}$, respectively. In all spectra, the absorptions of the $\mathrm{Fe}-\mathrm{O}$ and $\mathrm{Ni}-$ $O$ bonds give characteristic bands at $429-630 \mathrm{~cm}^{-1}$. The peaks at $1023,1149,1151 \mathrm{~cm}^{-1}$ are related to the Si-O-Si stretching

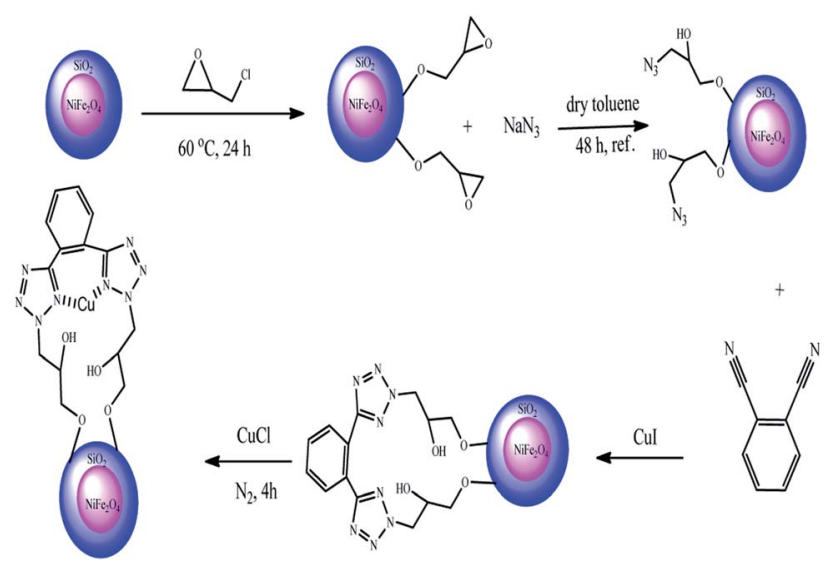

Scheme 1 Synthesis of the $\mathrm{NiFe}_{2} \mathrm{O}_{4} \mathrm{aSiO}_{2}$-tetrazol-Cu(I). 


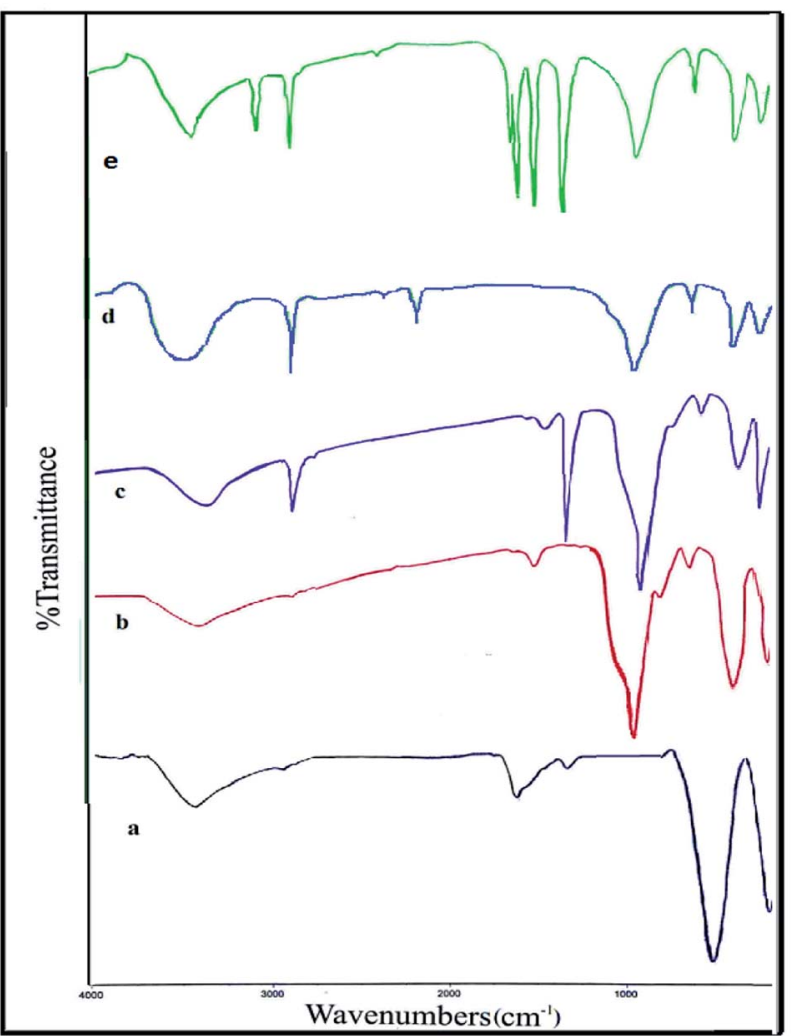

Fig. 1 FT-IR spectra of (a) $\mathrm{NiFe}_{2} \mathrm{O}_{4} \mathrm{NPS}$, (b) $\mathrm{NiFe}_{2} \mathrm{O}_{4} \mathrm{aSiO}_{2}$, (c) $\mathrm{NiFe}_{2} \mathrm{O}_{4} \mathrm{CSiO}_{2}$-epoxide, (d) $\mathrm{NiFe}_{2} \mathrm{O}_{4} \mathrm{CSiO}_{2}-\mathrm{N}_{3}$, and (e) $\mathrm{NiFe}_{2} \mathrm{O}_{4} \mathrm{a}$ $\mathrm{SiO}_{2}$-tetrazol.

vibrations in the $\mathrm{NiFe}_{2} \mathrm{O}_{4} @ \mathrm{SiO}_{2}, \mathrm{NiFe}_{2} \mathrm{O}_{4} @ \mathrm{SiO}_{2}$-epoxide and $\mathrm{NiFe}_{2} \mathrm{O}_{4} @ \mathrm{SiO}_{2}$-tetrazol spectra; therefore, $\mathrm{SiO}_{2}$ coated the surface of $\mathrm{NiFe}_{2} \mathrm{O}_{4}$.

In the $\mathrm{NiFe}_{2} \mathrm{O}_{4} @ \mathrm{SiO}_{2}$-epoxide spectrum, the bending vibration and stretching vibration of $\mathrm{CH}_{2}$ were attributed to the revealed bands at 1423 and $2922 \mathrm{~cm}^{-1}$, respectively. The absorption peaks at 1664,2921 and $3096 \mathrm{~cm}^{-1}$ in the FT-IR spectrum of $\mathrm{NiFe}_{2} \mathrm{O}_{4} @ \mathrm{SiO}_{2}$-tetrazol are related to the stretching vibrations of $\mathrm{C}=\mathrm{N}, \mathrm{C}-\mathrm{H}$ aliphatic, and $\mathrm{C}-\mathrm{H}$ aromatic, respectively. The $\mathrm{C}=\mathrm{C}$ vibrations were observed at 1481 and $1605 \mathrm{~cm}^{-1}$. The preparation of the final catalyst was proved by these described bands.

The stretching vibrations of $\mathrm{OH}, \mathrm{N}_{3}$, and the aliphatic $\mathrm{C}-\mathrm{H}$ group are shown in the FT-IR spectrum of $\mathrm{NiFe}_{2} \mathrm{O}_{4} @ \mathrm{SiO}_{2}-\mathrm{N}_{3}$ with absorption peaks at 3200-3600, 2080, and $2920 \mathrm{~cm}^{-1}$ respectively. The stretching vibrations of aromatic $\mathrm{C}-\mathrm{H}$, aliphatic $\mathrm{C}-\mathrm{H}$, and $\mathrm{C}=\mathrm{N}$ in the FT-IR spectrum of $\mathrm{NiFe}_{2} \mathrm{O}_{4}$ @$\mathrm{SiO}_{2}$-tetrazol showed absorption peaks at 3096, 2921, and $1664 \mathrm{~cm}^{-1}$, respectively. In addition, $\mathrm{C}=\mathrm{C}$ vibrations appeared at 1605 and $1481 \mathrm{~cm}^{-1}$.

The final product is without the nitrile groups of phthalonitrile, indicating its reaction with $\mathrm{N}_{3}$ and conversion to tetrazole..$^{38}$

Fig. 2 shows the powder XRD patterns of $\mathrm{NiFe}_{2} \mathrm{O}_{4} \mathrm{NPs}$ and $\mathrm{NiFe}_{2} \mathrm{O}_{4} @ \mathrm{SiO}_{2}$-tetrazol-Cu(I). A comparison of all the characteristic peaks of $\mathrm{NiFe}_{2} \mathrm{O}_{4}$ in the diffraction pattern with the
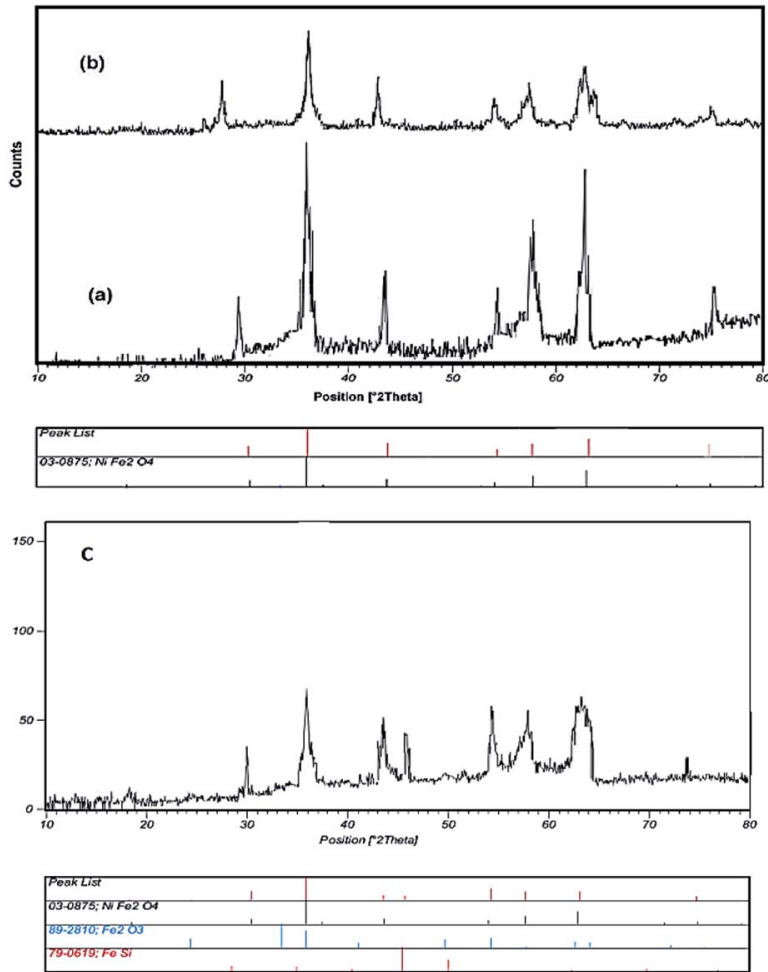

Fig. 2 The X-ray diffraction patterns of (a) $\mathrm{NiFe}_{2} \mathrm{O}_{4}$, (b) $\mathrm{NiFe}_{2} \mathrm{O}_{4} \mathrm{aSiO}_{2}$ tetrazol, and (c) $\mathrm{NiFe}_{2} \mathrm{O}_{4} \mathrm{aSiO}_{2}$-tetrazol-Cu(I).

standard XRD pattern (JCPDS file no. 03-0875) showed complete adaptability. The weaker diffraction lines in $\mathrm{NiFe}_{2} \mathrm{O}_{4} @ \mathrm{SiO}_{2}$ tetrazol and $\mathrm{NiFe}_{2} \mathrm{O}_{4} @ \mathrm{SiO}_{2}$-tetrazol-Cu(I) (Fig. 2b and c) are due to the $\mathrm{NiFe}_{2} \mathrm{O}_{4}$ coating.

The average diameter of the $\mathrm{NiFe}_{2} \mathrm{O}_{4}$ NPs and the final catalyst were calculated as 11 and $16 \mathrm{~nm}$, respectively in the Debye-Scherrer equation. The morphologies and particle sizes of $\mathrm{NiFe}_{2} \mathrm{O}_{4}$ and the final catalyst were characterized in the SEM image (Fig. 3).

The spherical morphology and uniform sizes of these nanoparticles were confirmed in this image and the average
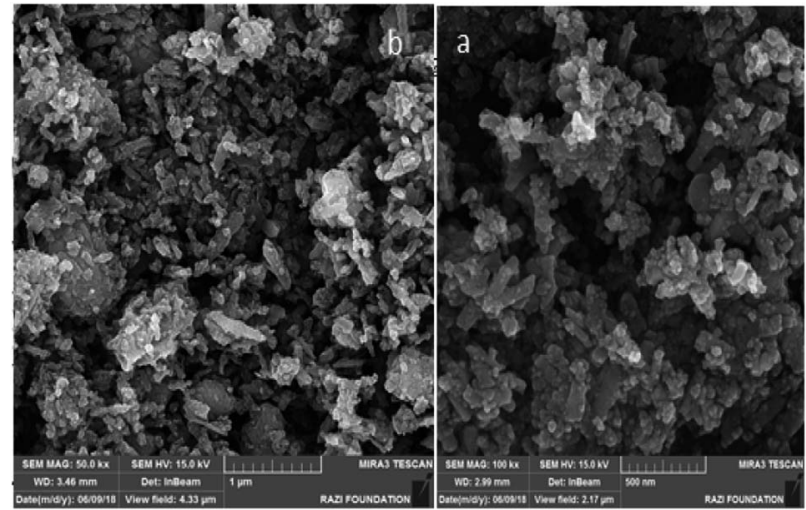

Fig. 3 SEM images of (a) $\mathrm{NiFe}_{2} \mathrm{O}_{4} \mathrm{NPs}$ and (b) $\mathrm{NiFe}_{2} \mathrm{O}_{4} \mathrm{CSiO}_{2}$-tetrazol$\mathrm{Cu}(1)$. 
diameters of both $\mathrm{NiFe}_{2} \mathrm{O}_{4}$ and $\mathrm{NiFe}_{2} \mathrm{O}_{4} @ \mathrm{SiO}_{2}$-tetrazol-Cu(I) were calculated to be about $8.7 \mathrm{~nm}$. The EDX spectra confirmed the preparation of $\mathrm{NiFe}_{2} \mathrm{O}_{4}$ and $\mathrm{NiFe}_{2} \mathrm{O}_{4} @ \mathrm{SiO}_{2}$-tetrazol-Cu(I) with the presence of $\mathrm{O}, \mathrm{Fe}$, and $\mathrm{Ni}$, and the presence of $\mathrm{C}, \mathrm{N}, \mathrm{Si}$ and $\mathrm{Cu}$, respectively, in addition to other elements in composites of these catalysts (Fig. 4).

The magnetic properties of $\mathrm{NiFe}_{2} \mathrm{O}_{4}$ and $\mathrm{NiFe}_{2} \mathrm{O}_{4} @ \mathrm{SiO}_{2}$-tetrazol-Cu(I) nanoparticles were investigated at room temperature (Fig. 5). A vibrating sample magnetometer (VSM) reported the saturation magnetization of $\mathrm{NiFe}_{2} \mathrm{O}_{4}$ NPs and the final catalyst as 16.7 and $6 \mathrm{emu} \mathrm{g}^{-1}$, respectively. The functionalization with organic groups and coating of magnetic NPs reduced the magnetic properties. The magnetic properties of these catalysts allowed them to be separated more easily by an external magnet.

The thermal stability of the magnetic nanocatalyst was investigated by thermogravimetric analysis (TGA). This analysis confirmed the presence of different groups on the surface of the nanoparticles and their thermal stability (Fig. 6). No change in weight before $380{ }^{\circ} \mathrm{C}$ indicated a lack of solvent in the structure of the catalyst and, of course, its high thermal resistance.

The degradation of organic groups covering the $\mathrm{NiFe}_{2} \mathrm{O}_{4}$ surface was observed in weight loss $(40 \%)$ at $380-800{ }^{\circ} \mathrm{C}$ in the TGA curve of $\mathrm{NiFe}_{2} \mathrm{O}_{4} @ \mathrm{SiO}_{2}$-tetrazol-Cu(I). As a result, this catalyst is suitable for organic synthesis due to its thermal stability up to $380{ }^{\circ} \mathrm{C}$.

\subsection{Investigation of catalytic activity}

To optimize reaction parameters and characterize the catalytic efficiency of the nanocatalyst, we considered the reaction of 4chlorobenzaldehyde ( $1 \mathrm{mmol}), 1,3$-indanedione $(1 \mathrm{mmol})$, barbituric acid ( $1 \mathrm{mmol})$, and ammonium acetate $(1.3 \mathrm{mmol})$ as a model reaction (Scheme 2).

The effects of different conditions including temperature, solvent, amounts of catalyst on the reaction were determined (Tables 1-3). According to Table 1, the water solvent was shown as the most suitable solvent among the other solvents used including EtOH, $\mathrm{MeOH}, \mathrm{CH}_{2} \mathrm{Cl}_{2}$ and dimethylformamide (DMF). Accordingly, the most suitable reaction temperature that increased the reaction efficiency in the shortest reaction time was determined to be $90{ }^{\circ} \mathrm{C}$ (Table 1 , entry 3 ).

Table 2 presents the effect of catalyst amount, $\mathrm{NiFe}_{2} \mathrm{O}_{4}$ @$\mathrm{SiO}_{2}$-tetrazol-Cu(I), on the synthesis of 1a. Here, $0.005 \mathrm{~g}$ of the catalyst was recorded as the best observed result and $94 \%$ of the product was obtained from the application of this amount of
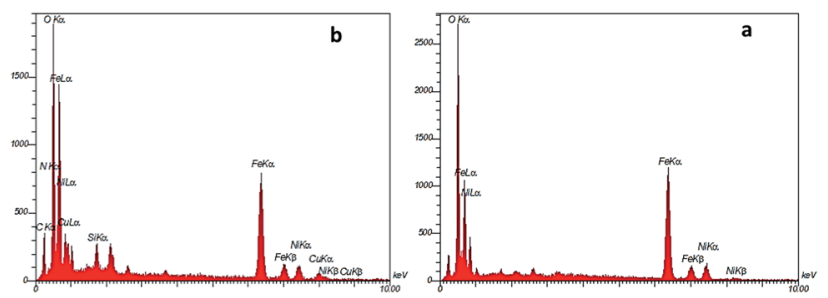

Fig. 4 EDX spectrum of (a) $\mathrm{NiFe}_{2} \mathrm{O}_{4} \mathrm{NPs}$ and (b) $\mathrm{NiFe}_{2} \mathrm{O}_{4} \mathrm{CSiO}_{2}$-tetrazol-Cu(I).

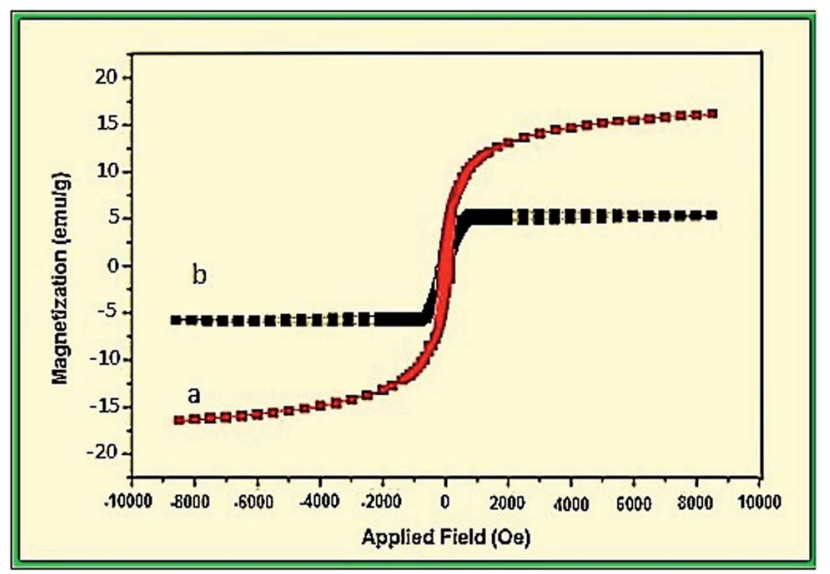

Fig. 5 Magnetization versus applied field for (a) $\mathrm{NiFe}_{2} \mathrm{O}_{4} \mathrm{NPs}$ and (b) $\mathrm{NiFe}_{2} \mathrm{O}_{4}\left(\mathrm{aSiO}_{2}\right.$-tetrazol-Cu(I).

catalyst in the reaction under reflux conditions at two hours (Table 2, entry 8). The substrates were placed in the reaction vessel without the catalyst under the defined conditions; after eight hours no product was obtained (Table 2, entry 11).

Each of the substituted aryl derivatives in the optimal conditions specified in the previous step presented a different yield of the product (Table 3 ). The high efficiency of the product and short reaction time have given a special advantage to electron-withdrawing substituents, especially the 4-nitro group with a $96 \%$ yield. However, the highest reaction time and the lowest yield were obtained for the 2-methyl group. Electron donation and the steric hindrance of the ortho position are two effective factors in generating this result. The structures of all products were confirmed by infrared (IR), ${ }^{1} \mathrm{H}$ NMR, and C.H.N analysis.

\subsection{Proposed reaction mechanism}

The mechanism shown in Scheme 3 strongly confirms the above observations and the catalyst effects. The effect of the metal complex catalyst on the carbonyl oxygen of the aldehyde provides a good electrophilic center for the nucleophilic attack of 1,3-indanedione. Thus, the intermediate $\mathbf{I}$ is formed from a Knoevenagel condensation. Another condensation between barbituric acid and ammonium acetate yielded the

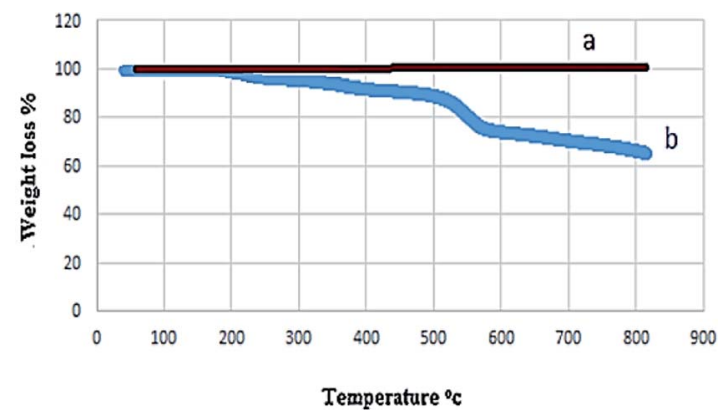

Fig. 6 TGA curve of (a) $\mathrm{NiFe}_{2} \mathrm{O}_{4} \mathrm{NPS}$ and (b) $\mathrm{NiFe}_{2} \mathrm{O}_{4} \mathrm{CSiO}_{2}$-tetrazol$\mathrm{Cu}(1)$. 


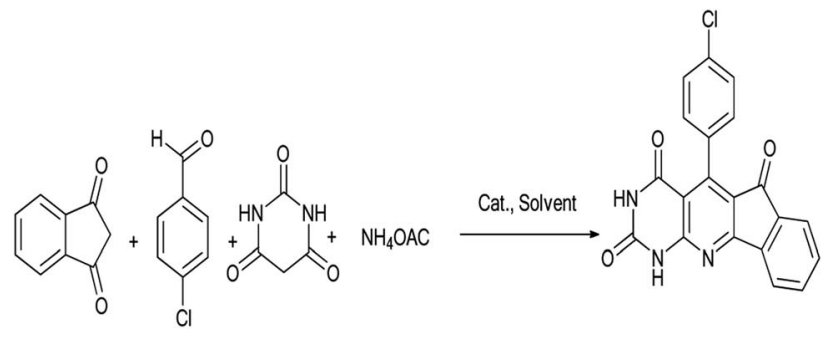

Scheme 2 Synthesis of indenopyridopyrimidine.

Table 1 Optimization of the solvent and temperature in model reaction $^{a}$

\begin{tabular}{llll}
\hline Entry & Solvent & $\begin{array}{l}\text { Temperature } \\
\left({ }^{\circ} \mathrm{C}\right)\end{array}$ & Yield $^{b}(\%)$ \\
\hline 1 & Water & 50 & 60 \\
2 & Water & 80 & 89 \\
3 & Water & 90 & 92 \\
4 & Ethanol & 50 & 55 \\
5 & Ethanol & 60 & 79 \\
6 & Ethanol & 70 & 85 \\
7 & Methanol & 40 & 45 \\
8 & Methanol & 50 & 67 \\
9 & Methanol & 70 & 70
\end{tabular}

${ }^{a}$ Reaction conditions: 4-chlorobenzaldehyde (1 mmol), 1,3indanedione $(1 \mathrm{mmol})$, barbituric acid $(1 \mathrm{mmol})$, and ammonium acetate $(1.3 \mathrm{mmol}){ }^{b}$ Isolated yields.

Table 2 Different amounts of catalyst in the model reaction ${ }^{a}$

\begin{tabular}{llll}
\hline Entry & Catalyst (mol\% or g) & Time $(\mathrm{h})$ & Yield $^{b}(\%)$ \\
\hline 1 & $\mathrm{NiFe}_{2} \mathrm{O}_{4} \mathrm{NPs}(3 \%)$ & 3.5 & 80 \\
2 & $\mathrm{NiFe}_{2} \mathrm{O}_{4} \mathrm{NPs}(2 \%)$ & 3 & 85 \\
3 & $\mathrm{NiFe}_{2} \mathrm{O}_{4} \mathrm{NPs}(1 \%)$ & 2.5 & 90 \\
4 & $\mathrm{NiFe}_{2} \mathrm{O}_{4} \mathrm{NPs}(0.5 \%)$ & 2 & 89 \\
5 & $\mathrm{NiFe}_{2} \mathrm{O}_{4} \mathrm{NPs}(0.3 \%)$ & 3 & 83 \\
6 & $\mathrm{NiFe}_{2} \mathrm{O}_{4} @ \mathrm{SiO}_{2}$-tetrazol-Cu(I) $(0.002 \mathrm{~g})$ & 2 & 80 \\
7 & $\mathrm{NiFe}_{2} \mathrm{O}_{4} @ \mathrm{SiO}_{2}$-tetrazol-Cu(I) $(0.001 \mathrm{~g})$ & 2.5 & 87 \\
8 & $\mathrm{NiFe}_{2} \mathrm{O}_{4} @ \mathrm{SiO}_{2}$-tetrazol-Cu(I) $(0.005 \mathrm{~g})$ & 2 & 94 \\
9 & $\mathrm{NiFe}_{2} \mathrm{O}_{4} @ \mathrm{SiO}_{2}$-tetrazol-Cu(I) $(0.0003 \mathrm{~g})$ & 3.5 & 79 \\
10 & $\mathrm{NiFe}_{2} \mathrm{O}_{4} @ \mathrm{SiO}_{2}$-tetrazol-Cu(I) $(0.0002 \mathrm{~g})$ & 4 & 75 \\
11 & $\mathrm{Without} \mathrm{catalyst}$ & 8 & 0
\end{tabular}

${ }^{a}$ Reaction conditions: 4-chlorobenzaldehyde (1 mmol), 1,3indanedione $(1 \mathrm{mmol})$, barbituric acid $(1 \mathrm{mmol})$, and ammonium acetate $(1.3 \mathrm{mmol}){ }^{b}$ Yields.

intermediate II (enamine). The interaction of two existing fragments gave the intermediate III. The desired product was achieved through intramolecular nucleophilic addition followed by the removal of water. According to observations, the role of catalytic activation in this process is very important.

\subsection{Reusability of catalyst}

The importance of the recyclability of heterogeneous catalysts in improving their performance in other reactions requires
Table 3 Synthesis of indenopyridopyrimidines (1a-12a) from various aromatic aldehydes under optimum conditions (h: reaction time, \%: product efficiency)
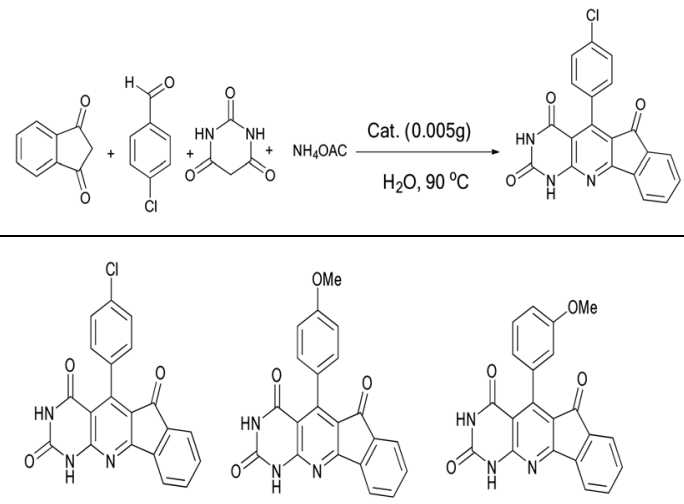

$94 \%, 2 \mathrm{~h}$

1a

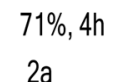

$79 \%, 3$ h
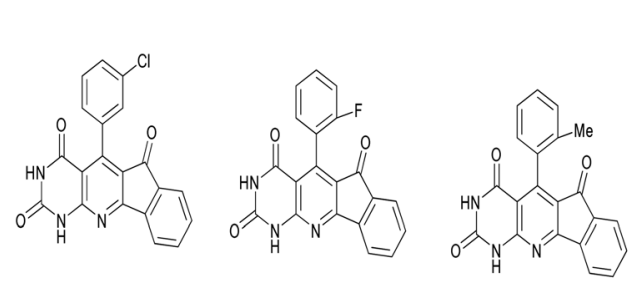

$83 \%, 3 h$

$90 \%, 2.5 \mathrm{~h}$

$63 \%, 4 h$

$4 a$<smiles>O=C1C(=O)c2c(nc3[nH]c(=O)[nH]c(=O)c3c2-c2ccc(Cl)cc2)-c2ccccc21</smiles>

$5 a$
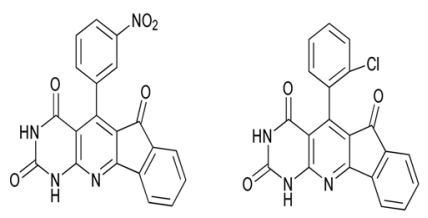

$91 \%, 2 \mathrm{~h}$

$7 a$

$$
84 \%, 3 h
$$

$8 a$
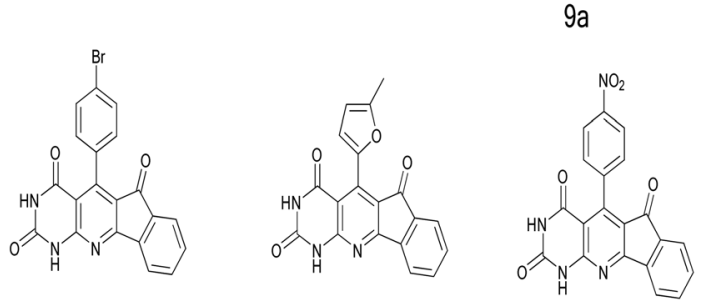

$90 \%, 2.5 \mathrm{~h}$

$90 \%, 2.5 h$

$96 \%, 2 \mathrm{~h}$

$10 \mathrm{a}$

$11 a$

$12 a$

a study on their sustainability. For this purpose, the catalyst was extracted from the reaction mixture using an external magnet and after rinsing several times with water and ethanol, it was dried at $80{ }^{\circ} \mathrm{C}$ in an oven for $9 \mathrm{~h}$ and reused in subsequent 


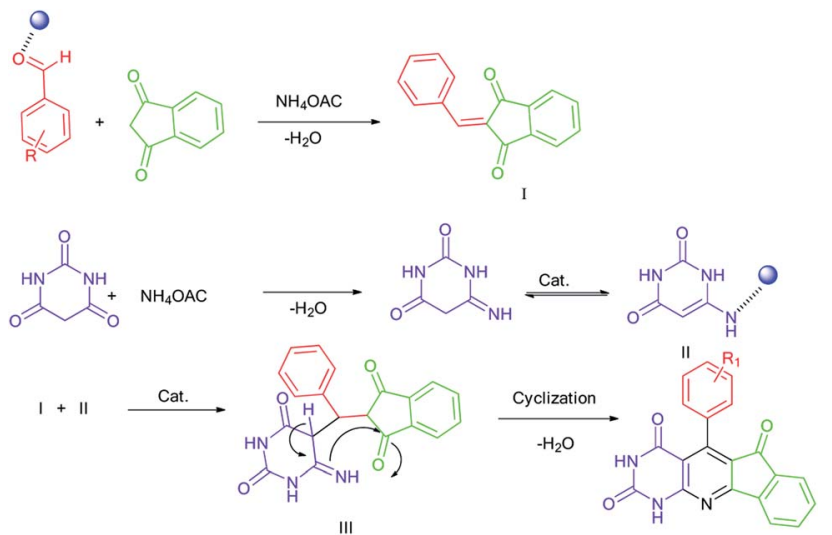

Scheme 3 The proposed reaction mechanism for the formation of $1 \mathrm{a}$ (O: $\mathrm{NiFe}_{2} \mathrm{O}_{4} \mathrm{aSiO}_{2}$-tetrazol-Cu(I)).

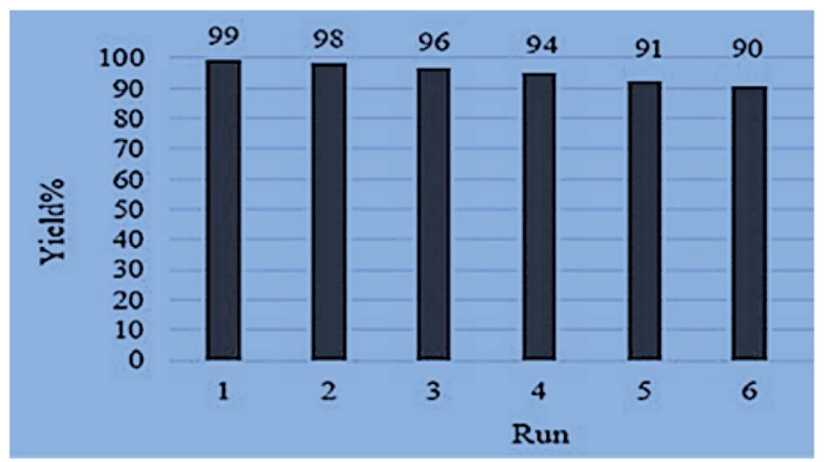

Fig. 7 Recyclability of $\mathrm{NiFe}_{2} \mathrm{O}_{4} \mathrm{CSiO}_{2}$-tetrazol-Cu(I) for the synthesis of $1 \mathrm{a}$.

reactions. Satisfaction of catalyst activity after being reused six times proves its recyclability and stability in repeated reactions (Fig. 7).

\section{Conclusions}

We have synthesized indenopyridopyrimidine compounds by using a designed catalyst to provide a green, efficient and convenient process with easy access to starting materials. This procedure provides a new synthetic route that uses readily available compounds and is low-cost with a short reaction time and a high percentage yield of the desired products. From another standpoint, we designed a heterogeneous catalyst covered with functional groups, which affects the progression of the reaction, is reusable in other reactions and provides a credible approach to the use of this pathway. FT-IR spectroscopy, SEM, TGA, EDX analysis, and XRD confirmed the synthesis of the catalyst.

\section{Conflicts of interest}

There are no conflicts to declare.

\section{Acknowledgements}

The authors are grateful to University of Kashan for supporting this work by Grant number 159148/85.

\section{Notes and references}

1 I. D. Bystryakova, I. A. Burova, G. M. Chelysheva, S. V. Zhilinkova, N. M. Smirnova and T. S. Safonova, Khim.Farm. Zh., 1991, 25, 31-35.

2 A. B. Deyanov, R. K. Niyazov, F. Y. Nazmetdinov, B. Y. Syropyatov, V. E. Kolla and M. E. Konshin, Khim.Farm. Zh., 1991, 25, 26.

3 A. Pastor, R. Alajarin, J. J. Vaquero, J. Alvarez-Builla, M. Fau de Casa-Juana, C. Sunkel, J. G. Priego, I. Fonseca and J. Sanz-Aparicio, Tetrahedron, 1994, 50, 8085-8098.

4 N. M. Evdokimov, S. V. Slambrouck, P. Heffeter, L. Tu, B. L. Calve, D. Lamoral-Theys, C. J. Hooten, P. Y. Uglinskii, S. Rogelj, R. Kiss, W. F. A. Steelant, W. Berger, J. J. Yang, C. G. Bologa, A. Kornienko and I. V. Magedov, J. Med. Chem., 2011, 54, 2012-2021.

5 A. Gangjee, A. Vasudevan, F. Queener and R. J. Kisliuk, Med. Chem., 1996, 39, 1438.

6 M. Manpadi, P. Y. Uglinskii, S. K. Rastogi, K. M. Cotter, Y. C. Wong, L. A. Anderson, A. J. Ortega, S. V. Slambrouck, W. F. A. Steelant, S. Rogelj, P. Tongwa, M. Yu. Antipin, I. V. Magedov and A. Kornienko, Org. Biomol. Chem., 2007, 5, 3865-3872.

7 I. O. Donkor, C. L. Klein, L. Liang, N. Zhu, E. Bradley and A. M. Clark, J. Pharm. Sci., 1995, 84, 661-664.

8 M. N. Nasr and M. Gineinah, M. Arch. Pharm., 2002, 6, 289.

9 A. Monge, V. Martinez-Merino, C. Sanmartin, F. J. Fernandez, M. C. Ochoa, C. Berllver, P. Artigas and E. Fernandez-Alvarez, J. Med. Chem., 1989, 24, 209-216.

10 A. Rosowsky, C. E. Mota and S. F. Queener, J. Heterocycl. Chem., 1995, 32, 335-340.

11 V. E. Kolla, A. B. Deyanov, F. Y. Nazmetdinov, Z. N. Kashina and L. P. Drovosekova, Pharmaceut. Chem. J., 1993, 27, 635636.

12 M. Ghashang, S. Guhanathan and S. Sheik Mansoor, Res. Chem. Intermed., 2017, 43(12), 7257-7276.

13 J. M. Khurana, A. Chaudhary, B. Nand and A. Lumb, Tetrahedron Lett., 2012, 53, 3018-3022.

14 S. Abdolmohammadi, S. Balalaie and M. Barari, Comb. Chem. High Throughput Screening, 2013, 16, 150.

15 N. M. Evdokimov, S. V. Slambrouck, P. Heffeter, L. Tu, B. L. Calvé, D. Lamoral-Theys, C. J. Hooten, P. Y. Uglinskii, S. Rogelj, R. Kiss, W. F. A. Steelant, W. Berger, J. J. Yang, C. G. Bologa, A. Kornienko and I. V. Magedov, J. Med. Chem., 2011, 54, 2012.

16 A. Baziar and M. Ghashang, React. Kinet. Mech. Catal., 2016, 118, 463.

17 M. Ghashang, Res. Chem. Intermed., 2016, 42, 4191-4205.

18 M. Dehbashi, M. Aliahmad, M. R. Mohammad Shafiee and M. Ghashang, Synth. React. Inorg., Met.-Org., Nano-Met. Chem., 2013, 43, 1301.

19 A. Domling and I. Ugi, Angew. Chem., Int. Ed., 2000, 39, 3168. 
20 M. N. Elinson, A. I. Ilovaisky, V. M. Merkulova, F. Barba and B. Batanero, Tetrahedron, 2013, 69, 7125-7130.

21 N. Chatani and T. Hanafusa, Bull. Chem. Soc. Jpn., 1990, 63, 2134-2135.

22 T. B. Poulsen, C. Alemparte and K. A. Jørgensen, J. Am. Chem. Soc., 2005, 127, 11614.

23 A. K. El-Shafei, A. A. Sultan, A. M. Soliman and E. A. Ahmed, Synth. Commun., 1995, 25, 3211-3217.

24 B. Sreedhar, A. S. Kumar and P. S. Reddy, Tetrahedron Lett., 2010, 51, 1891-1895.

25 B. V. Subba Reddy, A. Siva Krishna, A. V. Ganesh and G. G. K. S. Narayana Kumar, Tetrahedron Lett., 2011, 52, 3342-3344.

26 I. Ugi and A. Domling, Endeavour, 1994, 18, 115.

27 S. Heck and A. Domling, Synlett, 2000, 424.

28 P. K. Tapaswi and C. Mukhopadhyay, ARKIVOC, 2011, 10, 287-298.

29 I. O. Donkor, C. L. Klein, L. Liang, N. Zhu, E. Bradley and A. M. Clark, J. Pharm. Sci., 1995, 84, 661-664.

30 H. Naeimi and A. Didar, Ultrason. Sonochem., 2017, 34, 889895.

31 D.-Q. Shi, Y. Li and H.-Y. Wang, J. Heterocycl. Chem., 2012, 49, 1086-1090.

32 G. I. Shakibaei, A. Feiz, H. R. Khavasi, A. A. Soorki and A. Bazgir, ACS Comb. Sci., 2011, 13(1), 96-99.

33 M. T. Ramírez-Palma, J. Segura-Arzate, G. López-Téllez and E. Cuevas-Yañez, J. Chem., 2016, 853-860.
34 Y. Lee and A. H. Hoveyda, J. Am. Chem. Soc., 2009, 131(9), 3160-3161.

35 J. J. Van Veldhuizen, J. E. Campbell, R. E. Giudici and A. H. Hoveyda, J. Am. Chem. Soc., 2005, 127(18), 6877-6882.

36 C. Wei and C. J. Li, J. Am. Chem. Soc., 2002, 124(20), 56385639.

37 V. Lillo, A. Prieto, A. Bonet, M. Mar Díaz-Requejo, J. Ramírez, P. J. Pérez and E. Fernández, Organometallics, 2009, 28(2), 659-662.

38 R. Ghosh, L. Pradhan, Y. P. Devi, S. Meena, R. Tewari, A. Kumar, S. Sharma, N. Gajbhiye, R. Vatsa and B. N. Pandey, J. Mater. Chem., 2011, 21, 13388-13398.

39 K. Maaz, S. Karim, A. Mumtaz, S. K. Hasanain, J. Liu and J. L. Duan, J. Magn. Mater., 2009, 321, 1838.

40 Y. H. Deng, D. W. Qi, C. H. Deng, X. M. Zhang and D. Y. Zhao, J. Am. Chem. Soc., 2008, 130, 28-29.

41 H. R. Dehghanpour, M. H. Mosslemin and R. Mohebat, J. Chem. Res., 2018, 42(1), 35-39.

42 N. M. Evdokimov, S. V. Slambrouck, P. Heffeter, L. Tu, B. L. Calvé, D. Lamoral-Theys, C. J. Hooten, P. Y. Uglinskii, S. R. Kiss, W. F. A. Steelant, W. Berger, J. J. Yang, C. G. Bologa, A. Kornienko and I. V. Magedov, J. Med. Chem., 2011, 54(7), 2012-2021.

43 A. Elhampour, F. Nemati, H. T. Nahzomi and V. Mohagheghi, Res. Chem. Intermed., 2017, 43, 6737-6761. 